Journal of Jazz Studies vol. 7, no. 1, pp. 47-72 (Spring 2011)

\title{
Out of the Ordinary: Andrew Hill's "Verona Rag"
}

\author{
Jeffrey Lovell
}

On August 29, 1986, center stage at Japan's Mt. Fuji Jazz Festival, composer and pianist Andrew Hill— sporting a white, untucked tuxedo shirt with cuff links (but no bow tie), off-white trousers, white dress shoes, and trendy shades- seated himself at the piano and began to play an original ragtime composition entitled "Verona Rag." Even Hill's most ardent fans were probably caught off guard; some may have interpreted the performance as tongue-in-cheek. The Mt. Fuji festival had a modern slant, and Hill's distinctive aesthetic is usually associated with the jazz "avant-garde." But with Hill, of course, unpredictability was always the one thing to be expected.

Throughout his career, Hill unwaveringly pursued his own path while never abandoning his bebop roots. His piano technique is infused with Thelonious Monk's percussiveness and Bud Powell's fluid bebop lines, even when Hill loosens such approaches from their original harmonic underpinnings. Features of Hill's style include shifting tempos and meters, expressive dissonances, percussive chords, and angular melodic lines with elastic rhythmic phrasing. Tonality is maintained to various degrees in his melodic gestures, chord voicings, and formal periodicity, even when such devices are placed in quasi-tonal or even non-tonal environments. Hill's compositions tend to be well-conceived roadmaps, with specific (and quite taxing) parts and roles assigned, and a definite sense of harmonic direction and climax. Still, this compositional forethought hardly makes his performances safe or predictable. "The way I like to play is to perform each time with a new piece of music or with some kind of different instrumentation," Hill remarked in $1966 .{ }^{2}$

In Hill's hands, ragtime was no less personal or creative a musical statement, showcasing his ability to fruitfully synthesize his mature style with a historical idiom. This study will examine Hill's use of this unlikely genre, determining how "Verona Rag" both conforms to and departs from standard ragtime compositional models. "Verona Rag" testifies to how Hill's musical conception, however removed from the mainstream, signified on and embraced the entire lineage of jazz styles.

\footnotetext{
${ }^{1}$ Unreleased video footage of this and other performances from the 1986 Mt. Fuji Jazz Festival has been preserved by Manhattan Records, a parent company of Blue Note.

${ }^{2}$ Don Heckman, "Roots, Culture and Economics: An Interview with Avant-garde Pianistcomposer Andrew Hill,” Down Beat, May 5, 1966, 21.
} 


\section{BACKGROUND}

Andrew Hill was often reluctant to discuss his past, and his published biographical information is fraught with inaccuracies, often perpetuated by Hill himself. ${ }^{3}$ Only upon his passing (on April 20, 2007) was his date of birth confirmed by his family. Many accounts state that Hill was born in Haiti on June 30, 1937; he was actually born in Chicago in 1931 with no known Haitian descent. ${ }^{4}$ In 1991 he confessed to The Oregonian that he decided on a whim "why don't I become Haitian?" after moving to New York in $1961 .^{5}$ From an early age Hill displayed a natural gift for the arts, and he did it all—sang, tap danced, and played organ and accordion-on the streets and in local talent shows. ${ }^{6}$ Around the age of ten, according to his recollections, his act secured the top prize turkey at the annual Thanksgiving amateur hour held at Chicago's Regal Theater. ${ }^{7}$ As a teenager Hill learned stride and boogie-woogie piano, with Earl Hines and Albert Ammons as premier models (he met Hines by chance while delivering the Chicago Defender). ${ }^{8}$ Hill's main musical schooling, however, would be in bebop, the dominant jazz style of his teenage years. Alto saxophonist Charlie Parker, bebop's greatest exponent, let Andrew sit in with the band on one occasion. This was a profound formative experience, but ultimately pianist Bud Powell was a more identifiable stylistic model. The eighth-note lines Powell wove together in apparent effortlessness were imitated by many jazz pianists coming of age in the late 1940s and early 1950s. Hill indicated that Art Tatum and Thelonious Monk were also important influences early on, and that much time was spent transcribing their music. ${ }^{9}$ Hill also showed composing talent early on, impressing Yale professor and composer Paul Hindemith, who on visits to Chicago instructed Hill in orchestration. ${ }^{10}$

Hill fronted a trio at Roberts Lounge and Liquor (later "Roberts Show Club") and also backed several major artists passing through Chicago, including Roy Eldridge, Ben Webster, Miles Davis, and the Johnny Griffin-Eddie Lockjaw Davis two-tenor quintet. ${ }^{11}$ In 1961, Hill effectively left Chicago to accompany singer Dinah Washington on tour. After the tour Hill relocated to New York, connecting with players such as Jackie McLean, Clifford Jordan, and Kenny Dorham. This

\footnotetext{
${ }^{3}$ Heckman, 19.

${ }^{4}$ Andrew Hill obituary by Howard Mandel, posted April 20, 2007, on www.allaboutjazz.com (accessed August 6, 2008).

${ }^{5}$ The Oregonian, November 10, 1991, Lively Arts, 1.

${ }^{6}$ Bob Rusch, "Andrew Hill: Interview," Cadence 1, no. 10 (1976): 3.

${ }^{7}$ Chuck Berg, "Andrew Hill: Innovative Enigma," Down Beat, March 10, 1977, 16.

${ }^{8}$ Ted Panken, "Normally Unorthodox," Down Beat, January, 2001, 33.

${ }^{9}$ Liner notes by Leonard Feather for Black Fire, 1987 CD reissue, Blue Note CDP 7841512.

${ }^{10}$ Liner notes by Gary G. Vercelli for Verona Rag, Soul Note 121 110-1.

${ }^{11}$ Rusch, 3.
} 
brief spell was cut short in 1962 by a call from multi-reed instrumentalist Rahsaan Roland Kirk, who asked Hill to join the band in Los Angeles for extended engagements in California. ${ }^{12}$ This association with Kirk may have had a significant impact on Hill. Kirk was a pioneer in appropriating historical styles as a point of departure for his own forward-thinking aesthetic. That Hill would follow suit seems more than coincidental.

Blue Note, the independent label whose bread and butter was the stylings of hard bop artists during the 1950s and well into the 1960s, also became a leading proponent of musicians trying to break from the conventions of mainstream jazz. Hill's playing first caught the attention of Blue Note owner Alfred Lion in the fall of 1963, during a Blue Note session led by Hill's friend Joe Henderson. Lion quickly signed Hill, and his first session, Black Fire, was recorded just two months later. (Hill later remarked that Lion considered him "the last of his protégés besides Thelonious Monk and Herbie Nichols." ${ }^{13}$ ) Around this time, Hill took a hiatus from listening to other musicians' albums: "In listening to other people, you absorb their thoughts, however unconsciously... right now I have to concentrate on finding my own way." "From 1963 to 1970 Hill recorded around eighteen albums' worth of material for Blue Note. Almost all of this material stylistically blurred distinctions between the hard bop and free jazz camps. ${ }^{15}$

As Hill distanced himself from the jazz mainstream in search of his own voice, he became increasingly aware of his precarious position on the fringes of marketability. Work in traditional jazz venues was in particularly short supply. Starting in the late 1960s, Hill was among the first jazz artists to apply for and receive funding through patrons and other grants, much like musicians of the Western art tradition. ${ }^{16}$ Hill did not record as prolifically after his Blue Note years, but he seemingly transcended the problems most jazz artists faced in trying to remain true to their concept while appeasing the public. Though apprehensive of academia, Hill would eventually enter the ranks of university teaching. From 1970 to 1971 Hill was composer-in-residence at Colgate University; later, he served as associate professor at Portland State University and artist-in-residence at Harvard University and Bennington College.

Many critics have classified Hill's music as part of the second wave of the "avantgarde" school. Hill himself has described his music as "avant-garde," but the term does little to explain Hill's conception, which—unlike most "free jazz"-never

${ }^{12}$ Berg, 16. Hill can be heard playing piano and celeste with Kirk's band on the album Domino (CD reissue, Verve B000050J60).

${ }^{13}$ Hill interview with Fred Jung for www.jazzweekly.com, posted in 2002.

${ }^{14}$ Liner notes by Nat Hentoff for Point of Departure, 1987 CD reissue, Blue Note CDP 7841672.

15 David Rosenthal, Hard Bop: Jazz and Black Music 1955-1965 (New York: Oxford University Press, 1992), 165.

${ }^{16}$ Roger Riggins, “Andrew Hill: Quiet Pioneer,” Down Beat, January 18, 1973, 14. 
completely discarded a sense of tonal centricity, and rarely entered into total collective improvisation.

\section{ANALYSIS}

The ragtime genre underwent a significant resurgence in mainstream culture during the 1970s, prompted by new publications of Scott Joplin's rags, recordings of rags by prominent classical pianists, and the release of the motion picture The Sting. ${ }^{17}$ Sheet music for piano rags proliferated widely, including rags modified for student use. Ragtime finally solidified its status as legitimate repertoire for classical performers, and some composers resuscitated the historical genre for innovative new compositions. ${ }^{18}$ Hill's choice of ragtime may seem less extraordinary in this context, though he was hardly known for gravitating toward popular trends.

In "Verona Rag," Hill's stylistic trademarks are evident on varying levels, despite the unusual choice of genre. Does the convergence of Hill's style and the traditional ragtime idiom result in an organic and cohesive piece? Or is the friction caused by these contrasting styles more the intended effect? We can first make some general comparisons between "Verona Rag" and traditional rags in terms of formal structure. A transcription of "Verona Rag" is included in the appendix of this study. The transcription and analysis in this study are derived from the Milan studio recording $^{19}$ of July 5, 1986, not the live recording made at the Mt. Fuji festival the following month.

Ragtime compositions generally follow a set formal scheme. A typical rag is comprised of four distinct repeated strains (labeled A, B, C and D), each 16 bars long and made up of two 8-bar phrases, the first phrase ending with a half-cadence and the second phrase ending with an authentic cadence. Strains can often be further subdivided into 4-bar phrases, creating double period structures. The $\mathrm{A}$ and $\mathrm{B}$ strains are usually built around the same key. At the beginning of the $\mathrm{C}$ strain, rags usually modulate to the subdominant and remain there for the $\mathrm{D}$ strain right through to the ending. Prior to this modulation, the A strain normally returns. Thus the standard ragtime form is AABBACCDD. ${ }^{20}$ In contrast to this model,

\footnotetext{
${ }_{17}$ Among the first studies of ragtime are Edward Berlin's Ragtime (Berkeley: University of California Press, 1980) and John Edward Hasse's Ragtime: Its History, Composers, and Music (New York: Schirmer Books, 1985). Regarding the 1970s ragtime revival, see Berlin, 179-182, and Hasse, 34-36.

${ }^{18}$ For especially rewarding examples, listen to William Bolcom's suite "The Garden of Eden" (from Bolcom Plays His Own Rags, Jazzology JCE-72) and Henry Martin's "Praeludium et Fuga XIII in Gb Major (A Slow Drag)" (from Preludes and Fugues, Part 2, Bridge 9140).

${ }^{19}$ This performance of "Verona Rag" was originally released on the album Verona Rag, Soul Note 121 110-1.

${ }^{20}$ Another formal structure found in traditional rags follows the strain sequence ABCD. A single occurrence of the rondo form ABACA appears in Joplin's "Euphonic Sounds."
} 
"Verona Rag" has no fewer than six strains, ordered AABBCCDEEFFAABBCCDEEFFAABB, plus a concluding four-measure tag. ${ }^{21}$ This high number of strains is not without precedent. "Pineapple Rag," one of Scott Joplin's later pieces, contains seven strains (ordered AABBACCDDEEFFEGGE) with striking chromatic shifts from strain to strain. ${ }^{22}$ But Hill departs even further from the standard model by a) not returning to the A strain immediately following the $\mathrm{B}$ strain; b) repeating the entire form of the rag; and c) returning yet again to the A and $B$ strains to conclude the piece and reestablish the original key. Thus the $A$ and B strains serve as the pillars of the overall form. At the hyper-formal level, Hill's strain pattern resembles a large-scale quasi-rondo form:

\section{$(\mathrm{AABB})(\mathrm{CCDEEFF})(\mathrm{AABB})(\mathrm{CCDEEFF})(\mathrm{AABB})=\mathrm{ABAB} A$}

On his second time through the C, D, E and F strains, Hill de-emphasizes the strict left-hand stride figures, blurring the regular pulse while developing and transforming the thematic material. These four strains become solo sections, elongated through improvisation based on fragments of the melodic gestures in each pre-written theme. Thus the structural melodic components of these strains remain intact, even when the original order of these melodic components is altered. Hill also clearly articulates the end of each strain - thus emphasizing the sectional structure - with a cadence on the dominant of the key he is modulating to.

The two main tonal areas that Hill explores in "Verona Rag" are a third apart, rather than the conventional fourth apart. The $\mathrm{A}$ and $\mathrm{B}$ strains are built around $\mathrm{G}$ major. In most ragtime the $\mathrm{C}$ strain begins with a modulation to the subdominant, but the $\mathrm{C}$ strain of "Verona Rag" is in B $b$ major, up a minor third. For the D strain, Hill shifts back down to $G$, but now emphasizes the minor mode. For a moment within this section, Hill briefly but significantly shifts to $\mathrm{B}$ major before returning to $\mathrm{G}$ minor, further emphasizing the composition's third relationships. The $\mathrm{E}$ and $\mathrm{F}$ strains return to $\mathrm{B} b$ major, after which the entire six-strain form is repeated, reestablishing $\mathrm{G}$ major. Joplin likewise alludes to third relationshipsbetween strains in "Pineapple Rag." This rag, which begins in $\mathrm{D} b$, makes the expected shift up a fourth to $\mathrm{G} b$ for the $\mathrm{C}$ strain. At the start of the $\mathrm{E}$ strain, however, the tonal center moves unexpectedly from $\mathrm{G} b$ to A major, an enharmonic minor third away (see Example 1). Then, in a manner similar to "Verona Rag," Joplin descends back down a third, this time to the minor mode of $\mathrm{G} b$.

\footnotetext{
${ }^{21}$ Hill noticeably abridges the strain sequence during his performance of "Verona Rag" at the Mt. Fuji Jazz Festival, likely due to time constraints. In his second time through the form, he does not repeat any strains, and omits the B strain entirely. The B strain is also omitted at the end. Thus the overall form of the piece in this rendition is: AABBCCDDEEFFAACDEFA-tag. This crops the piece from 16:33 down to approximately 13 minutes.

22 "Pineapple Rag" was first published in 1907, the same year Joplin composed Treemonisha.
} 
PINEAPPLE RAG

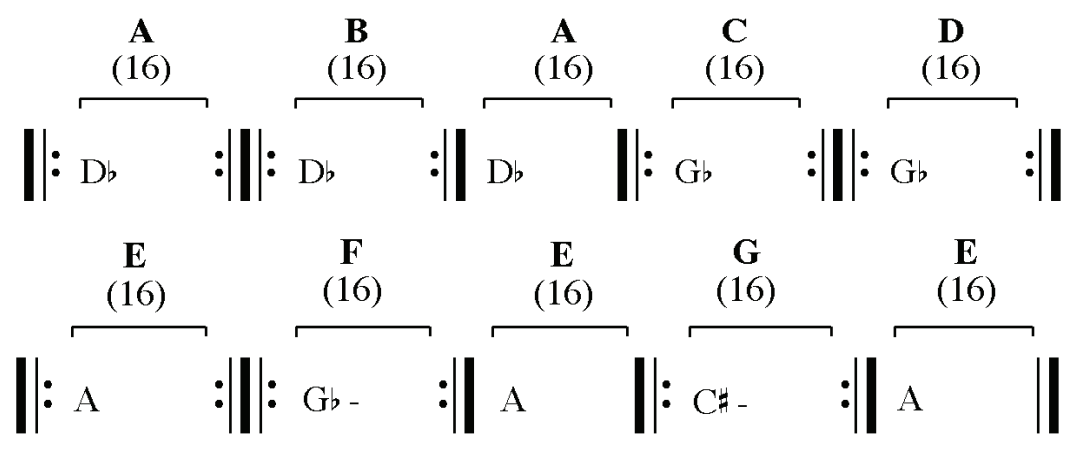

VERONA RAG
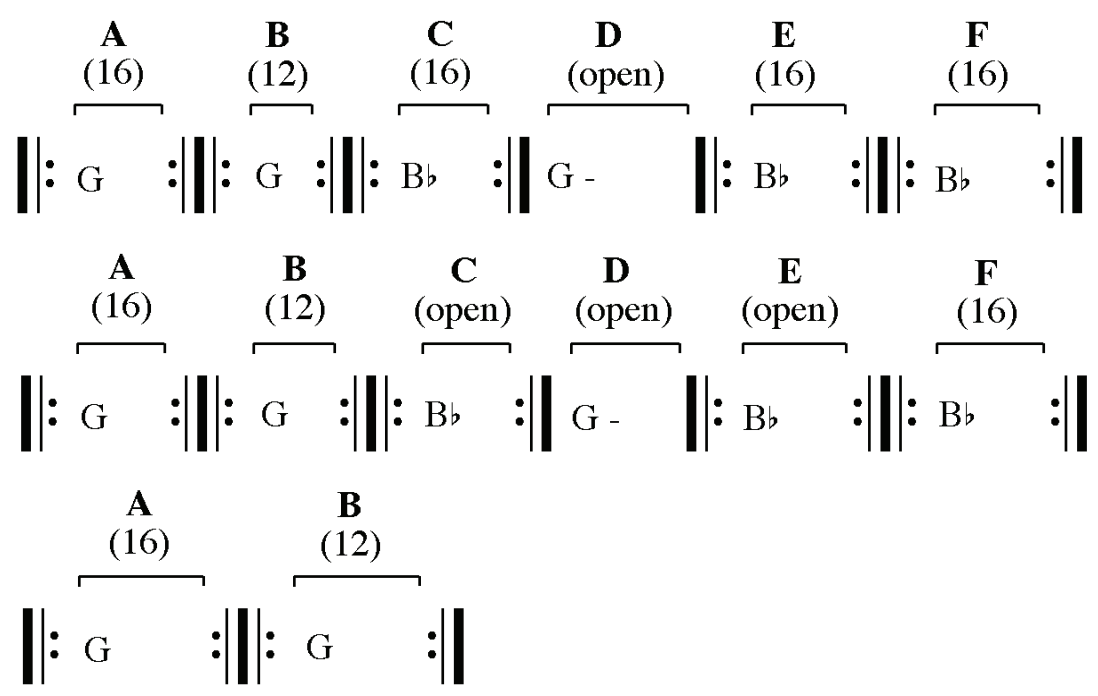

Example 1. Comparison of tonal areas in "Pineapple Rag" and "Verona Rag."

While third relationships between strains are not typical of traditional ragtime pieces, Hill does stick to traditional, functional harmony within each strain (the one exception is the D strain, discussed below). This employment of standard chord relationships makes "Verona Rag" something of an anomaly among Hill's compositions. Hill usually applied vertical structures in more unconventional ways, while rarely abandoning tonality altogether. With "Verona Rag," standard chord relationships strengthen the link to the historical ragtime model.

As noted, the first two strains of "Verona Rag" serve as pillars of the form, providing overall balance and symmetry. We can also express their function and significance by examining the melodic content in relation to the other strains. From 
both a melodic and harmonic standpoint, the material introduced in the A and $\mathrm{B}$ strains is derived from "I've Decided to Make Jesus My Choice" (Example 2), an

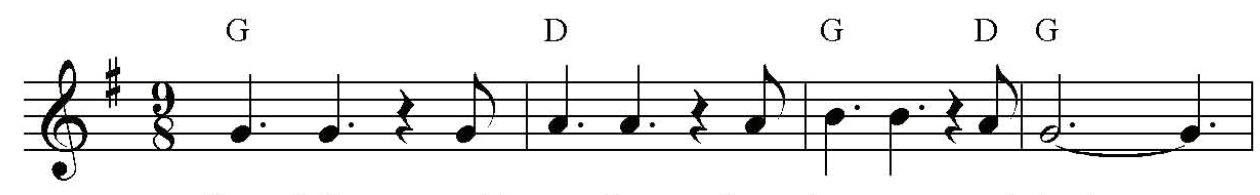

Some folks would ra-ther have hou-ses and land.

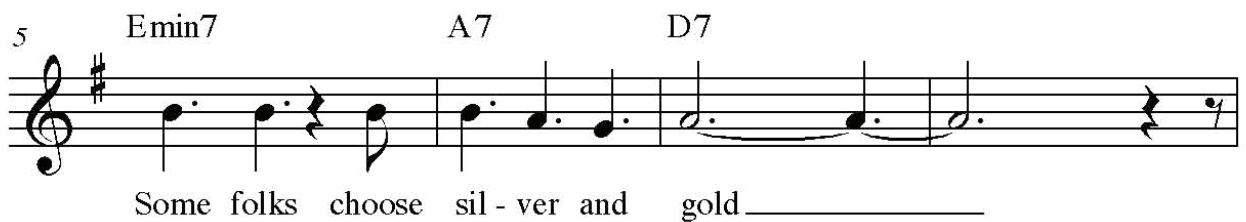

Some folks choose sil-ver and gold
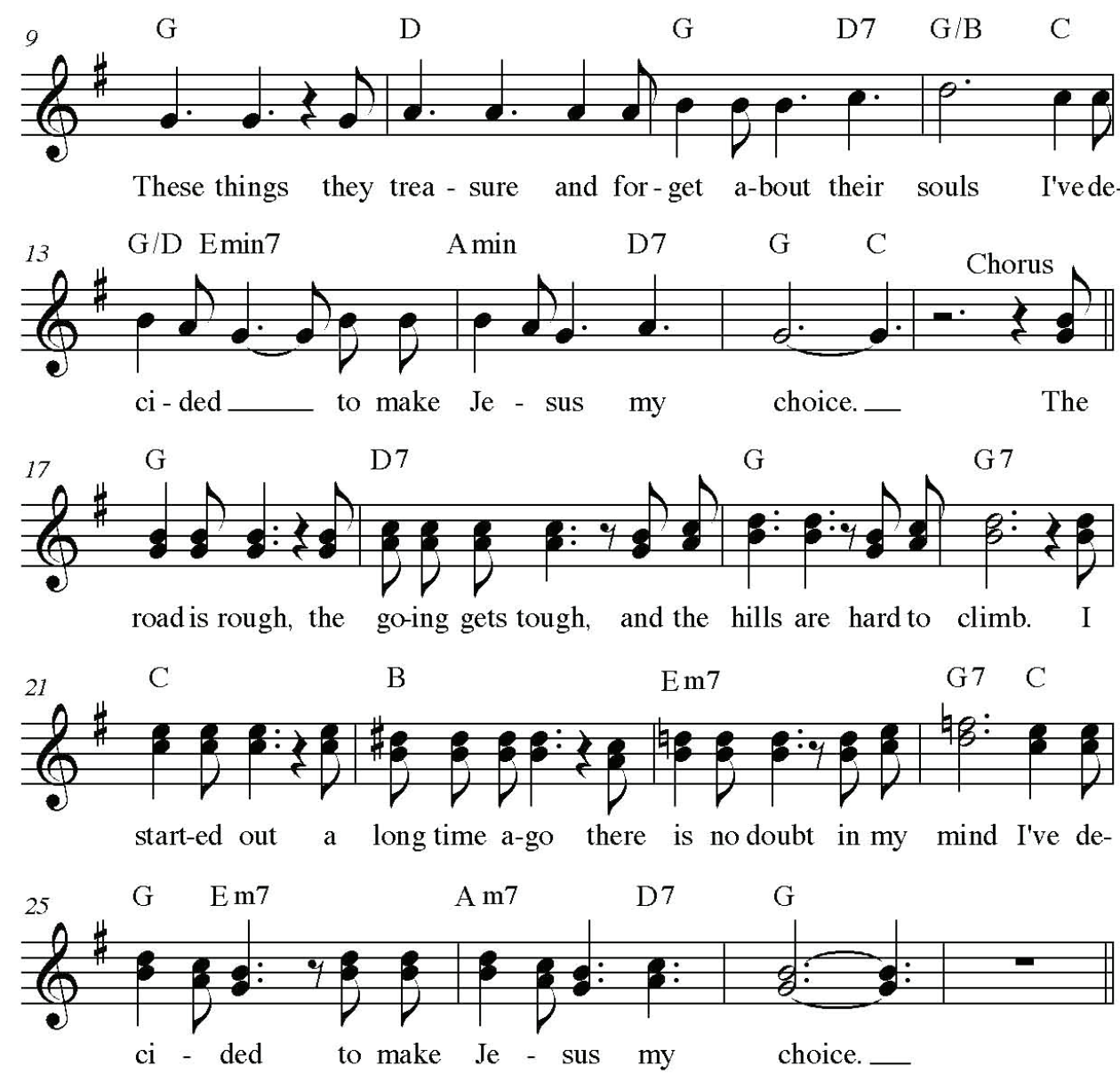

Example 2. Verse and chorus of "I've Decided to Make Jesus My Choice" (public domain). 
exclamatory religious spiritual and common repertory piece among gospel choirs. ${ }^{23}$ The lyrics to "I’ve Decided to Make Jesus My Choice" articulate a universal Christian message about avoiding worldly enticements in favor of the promise of heavenly reward. Both the spiritual and Hill's A and B strains follow the same chord sequence and chord structure. Hill also captures the main structural components of the spiritual's melody, but alters its somber feel, replacing the slow nine-eight pulse idiomatic to gospel music with the simple, bouncy quadruple meter of the rag. Casual listeners to "Verona Rag" are not likely to perceive any reference to the gospel idiom in the opening two strains.

The 16-bar verse is divided into two 8-bar phrases and follows the normal periodic formula, with a half cadence in measures 7-8 and an authentic cadence in measures 11-12. The main melodic gesture of the verse, as seen in the first four bars, is the stepwise ascending motion of a third, descending back to the tonic (G4) in reverse order. The second, adjoining 4-bar phrase begins on the third (B4) and similarly descends stepwise to the tonic before stepping back up to A4 in measure 7. The second half of the verse starts like the first, with ascending stepwise motion to $\mathrm{B} 4$, but then continues to climb, peaking at D5 before stepping back down to cadence on G4.

Using multiple levels of reduction, Example 3a examines how Hill's "variation” lines up with and differs from the original melody. For purposes of clarity, the melody of the spiritual has been reduced to its more fundamental pitches. "Verona Rag" is presented in its complete form at level "c," while levels "b" and "a" present successive melodic reductions in strict analytic notation that reveals the basic structures Hill embellishes upon. At these levels, notes with stems are more structural than unstemmed notes. ${ }^{24}$ At certain moments in the form, Hill keeps the basic shape of the spiritual's original line intact. In the opening two bars, howeverinstead of ascending stepwise from G4 to B4 (mm. 1-3)-Hill approaches the B4 from the opposite direction, descending from the $\mathrm{D}$ above. This contrasting melodic movement is most clearly observed by comparing the spiritual's original melody to level "a" of the rag. After reaching B4, both melodies continue downwards, reaching the tonic of $\mathrm{G}$ at the same time for the closure of the initial 4-bar phrase.

\footnotetext{
${ }^{23}$ Two fine renditions of "I've Decided to Make Jesus My Choice" are found on the albums The Harrison Johnson Los Angeles Community Choir is Here (Creed 3026) and Faith Will Survive: Isaac Douglas and the New York City Community Choir (Creed 3027).

${ }^{24}$ Strict use of analytic notation is a Schenkerian reductive system developed by Dr. Steve Larson; see his article "Strict Use of Analytic Notation," Journal of Music Theory Pedagogy 10 (1996): 3171.
} 


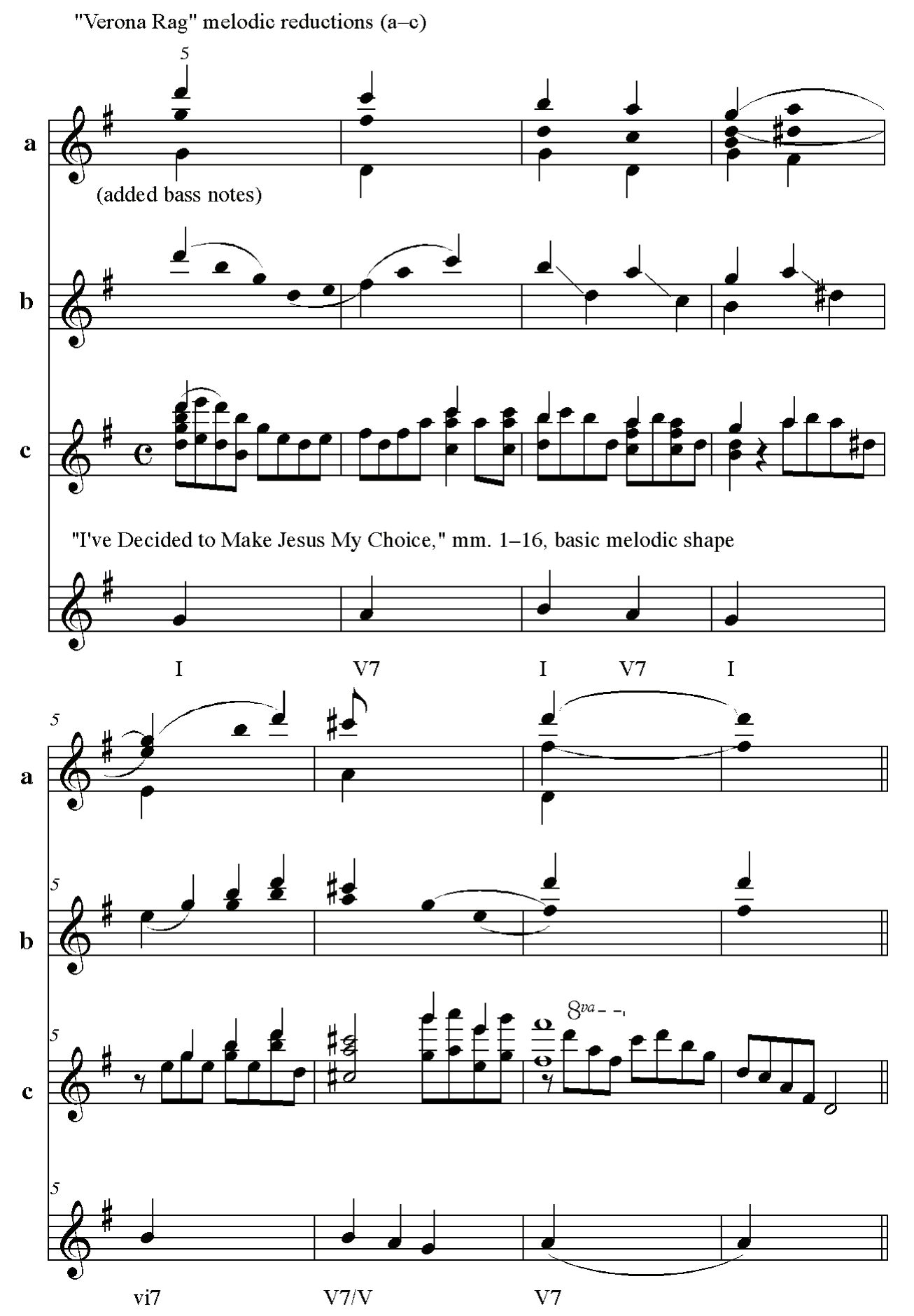

Example 3a. A strain of "Verona Rag" and verse of "I've Decided to Make Jesus My Choice" (continued on next page). 
a

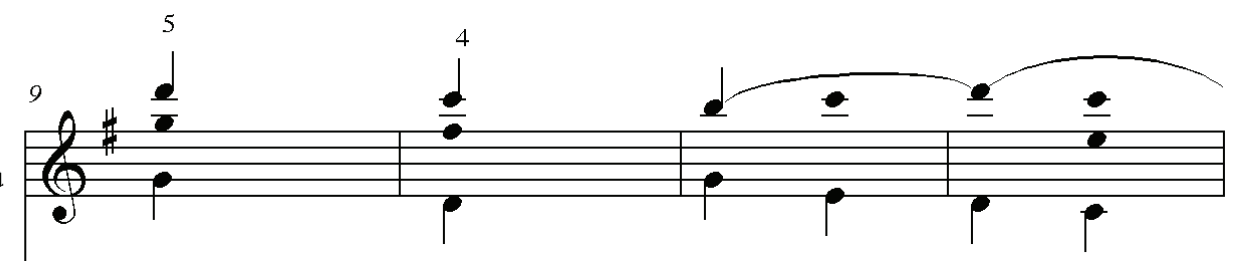

b

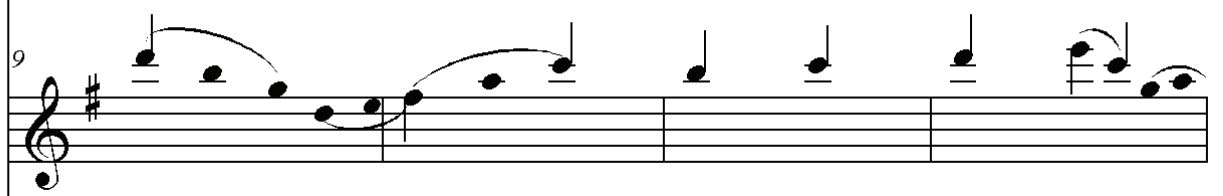

c

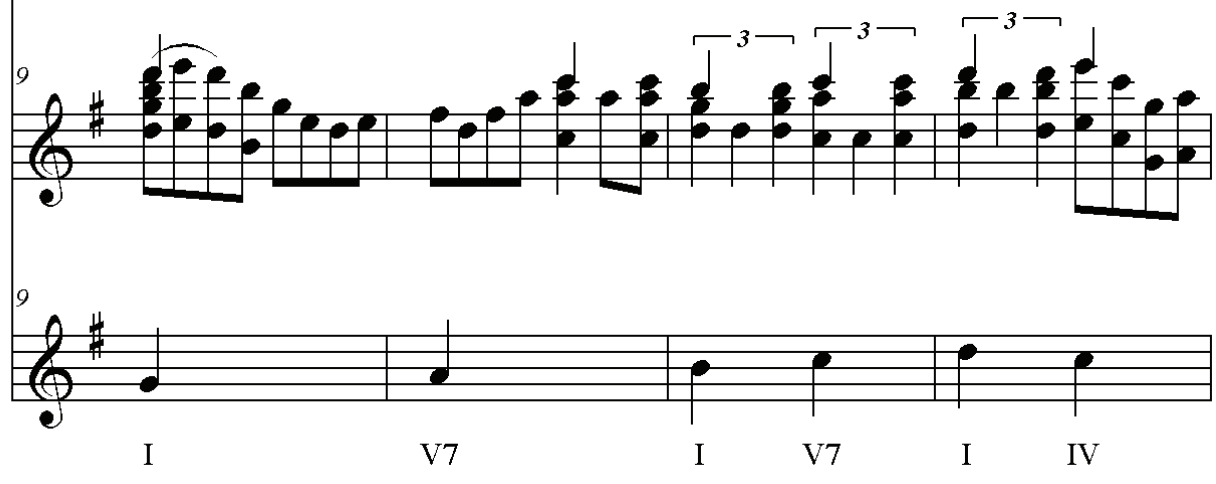

a

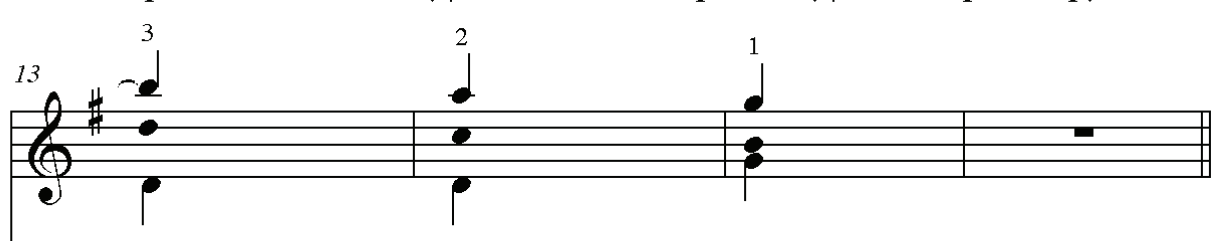

b

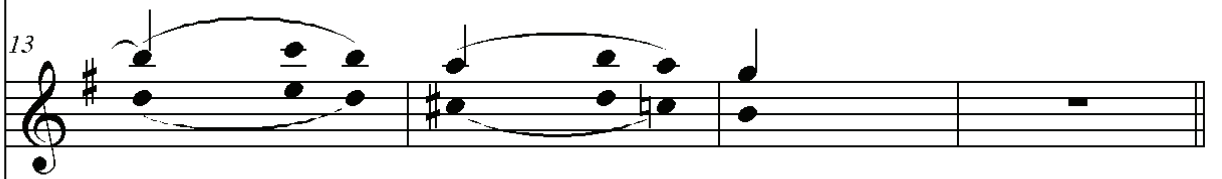

c

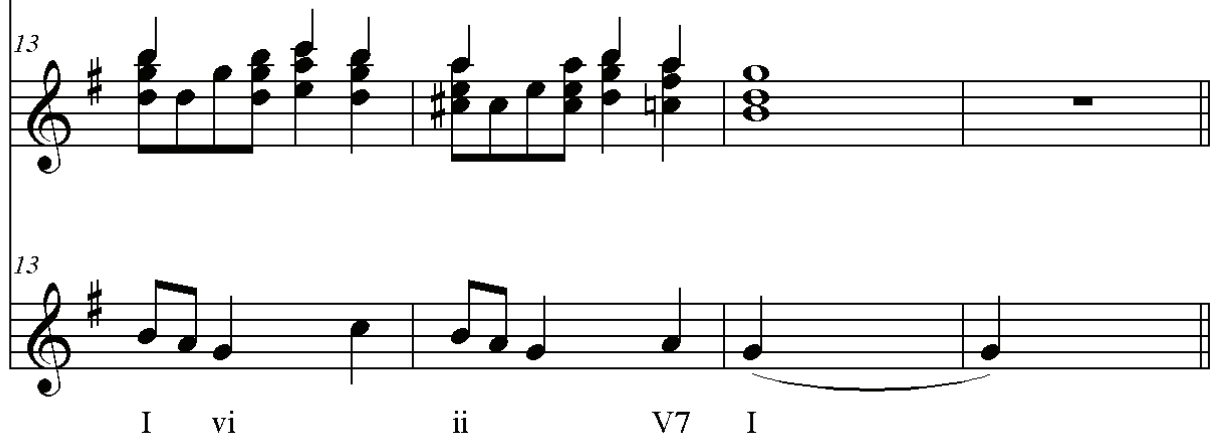

Example 3a, continued. 
In the second 8-bar phrase of the A strain, Hill articulates the corresponding phrase of the spiritual more precisely (in Example 3a, measures 9-12, compare level "a" to the spiritual melody). The spiritual intensifies with an ascending melodic line, and at measure 12, the tension climaxes with the word "souls" on D6, the highest note of the section. The rag's melody leading up to measure 12 incorporates most of the structural pitches of the spiritual, so Hill clearly wanted his climax to arrive at the same moment. This deliberate coinciding is further reinforced by more pronounced rhythmic figures. Hill also retains the basic descending, cadential gesture - the "mi-re-do" motive in measures 13-15 on structural level a-which closes this section of the spiritual. This motive is present on multiple levels. At level c, the motive appears on the last two beats of measure 14 and the first beat of measure 15 , part of a larger neighbor motion as can be seen at level $b$.

While the A strain represents the main verse of the spiritual, the B strain appropriates the spiritual's chorus. Example $3 \mathrm{~b}$ lines up the B strain and the chorus, which are both 12 measures long (the other five strains of "Verona Rag" are the standard 16 measures). As with Example 3a, the melody of the spiritual is reduced to its essential contour, while level c is the full written version of "Verona Rag," and levels $\mathrm{b}$ and $\mathrm{a}$ are successive levels of Schenkerian melodic reduction. As with the A strain, the melodic material of the B strain is woven around and follows the contours of the underlying spiritual.

For the B strain - much like the A strain — the stepwise ascending and descending line of the spiritual is retained. Hill's tendency to voice the melody in thirds also relates to the spiritual melody. In recordings of "I've Decided to Make Jesus My Choice," the melody of the chorus (and sometimes the verse) is sung in harmony a third above the main melodic line.

Of all the strains of "Verona Rag," Hill performs the first two strains with the least variation. This likely explains why these strains are paired together for three repetitions in the form. Hill breaks with the traditional ragtime sequence by returning to the $\mathrm{A}$ and $\mathrm{B}$ strains in the middle and at the end of the piece, and this large-scale formal change further emphasizes the spiritual on which both strains are constructed.

Within the $A$ and $B$ strains, the chord progressions and melodic figurations bear the marks of a traditional rag. With the $\mathrm{C}$ strain, however, Hill plants his musical fingerprints more directly on the melodic texture and harmonic sequence. The key of $\mathrm{B} b$ major is established in the first measure, but the harmony quickly becomes ambiguous as fragmented harmonic motion around the circle of fifths blurs the tonal center during the next six measures. A brief shift to $\mathrm{D}$ minor is alluded to at the end of the first 4-bar phrase, and in measure $8, \mathrm{~B} b$ major is re-established with an interesting harmonic shift to a half cadence. (For the full chord sequence of the C strain, see the appendix.) 
"Verona Rag" melodic reduction (a-c)

a

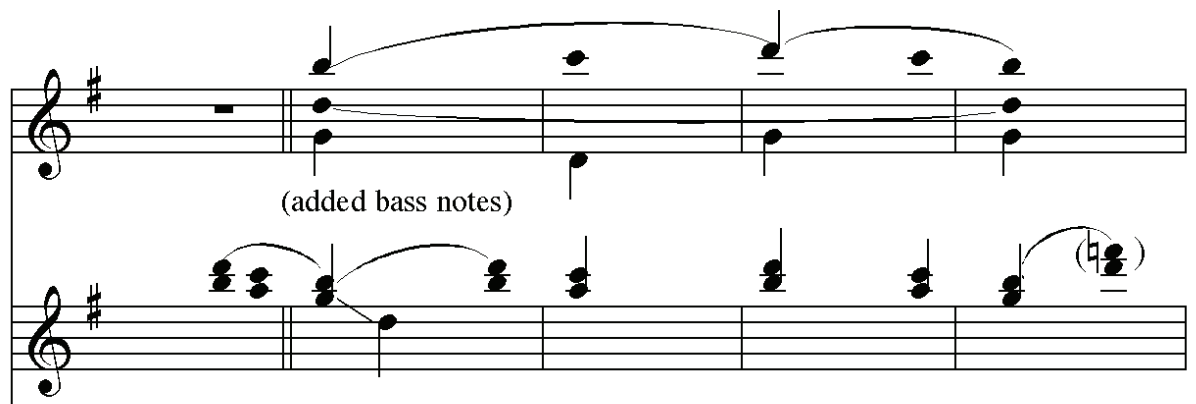

c

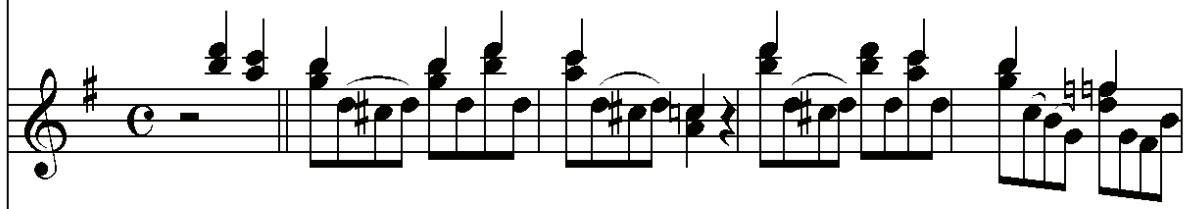

"I've Decided to Make Jesus My Choice," mm.17-28, basic melodic shape

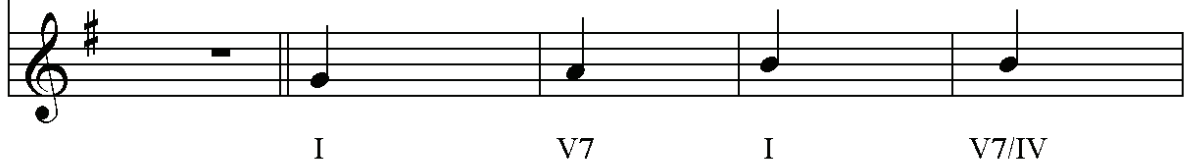

$\mathbf{a}$

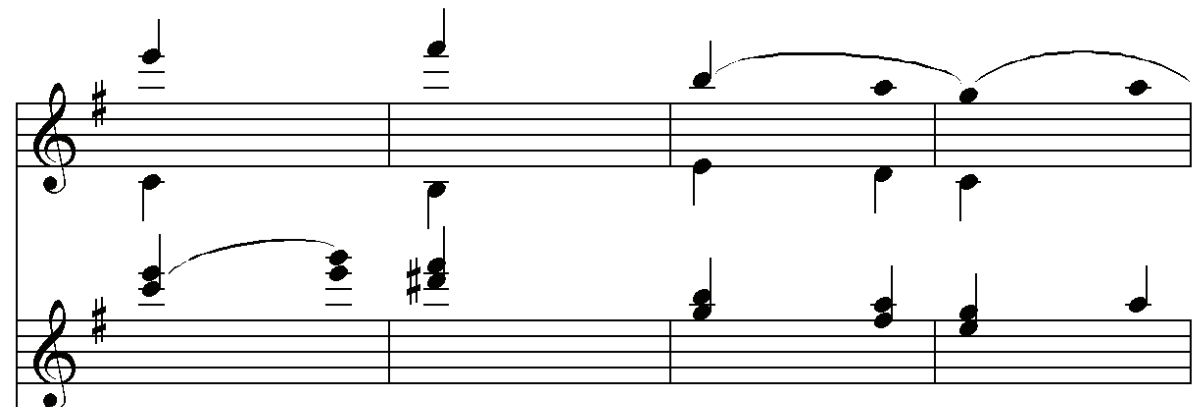

c

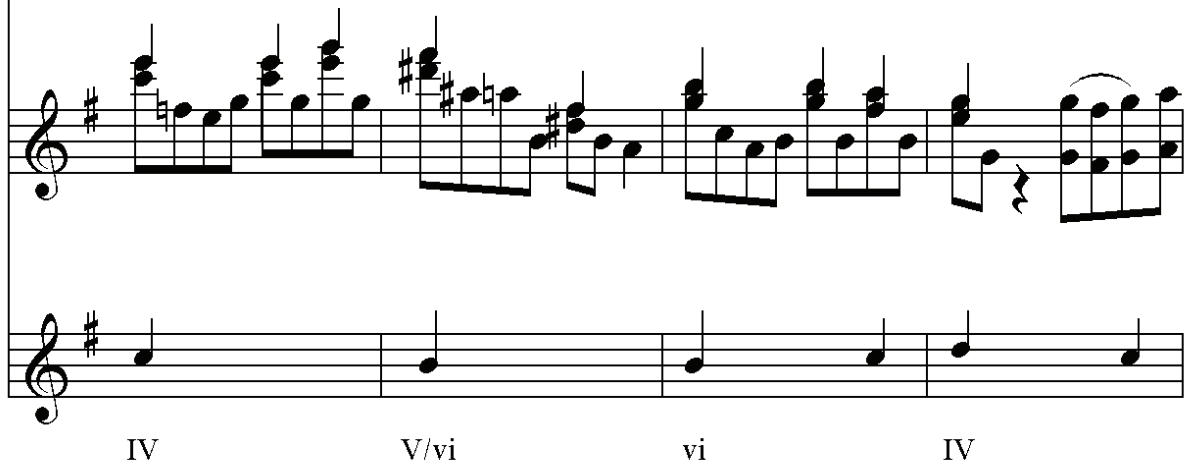

Example 3b. B strain of "Verona Rag" and chorus of "I've Decided to Make Jesus My Choice" (continued on next page). 


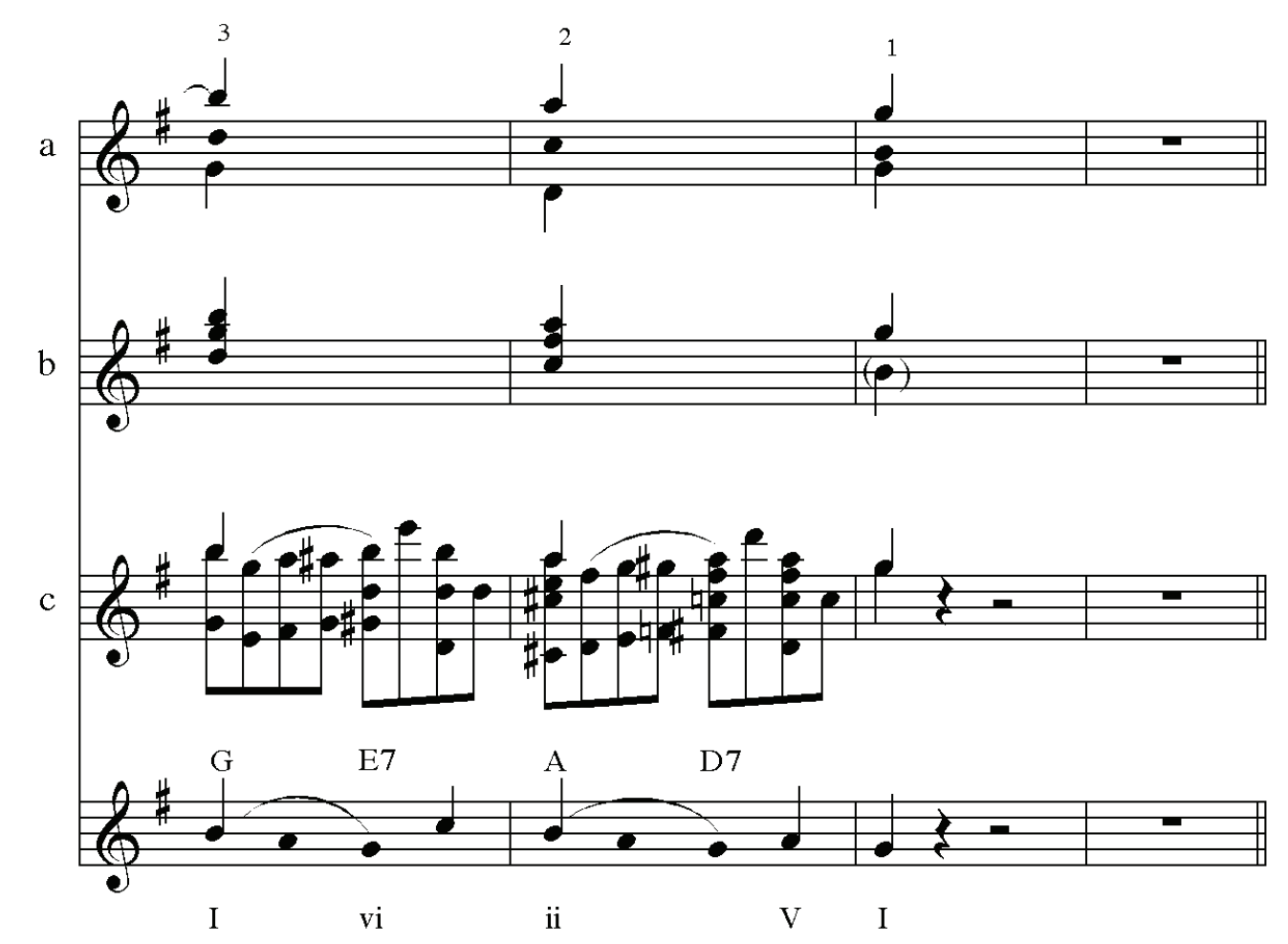

Example 3b, continued.

In performing the $\mathrm{C}$ strain, Hill increasingly offsets the melodic right hand figures by letting his hands fall rhythmically out of phase, with the melodic material placed farther behind the pulse. The melody maintains a "rocking" rhythmic quality characteristic of ragtime, with chords alternating with single pitches on the offbeat. But by the fifth measure, Hill voices the melody in dyads a major second apart, instead of the thirds that are prevalent in the first two strains.

In the D strain, Hill subtly inserts the spiritual's metrical feel, which he had extracted from the A and B strains. This dissection and displacement of "I've Decided to Make Jesus My Choice" lends a deeper (albeit more disguised) cohesiveness to the overall piece. To listeners unaware that Hill used this spiritual as source material, the D strain comes across as an island unto itself, little connected to other strains of the piece (except for the $\mathrm{G}$ minor tonal center, which parallels the $\mathrm{G}$ major key of the $\mathrm{A}$ and $\mathrm{B}$ strains). Gone are the stride patterns and tuneful melodies of the rag. Here Hill finally seems to liberate the expressiveness of the text and the conflict it describes: "The road is rough, the going gets tough..." The shift to the minor, coupled with chromatically compacted chord voicings, instantly project an aura of introspection and soul searching. It is as if Hill is offering his own interpretation of the text's meaning, drawing out the sensuality of "I've Decided to 
Make Jesus My Choice" without directly referencing its melodic content. Hill plays more freely at the beginning of the strain, so that the time feels suspended even though the nine-eight meter is still very much present.

The $\mathrm{D}$ strain begins in $\mathrm{G}$ minor, but shifts to $\mathrm{F}$ minor, $\mathrm{B}$ major and-for an extended period-A minor. Essentially, the $\mathrm{D}$ strain resembles an $\mathrm{ABA}^{\prime}$ form, demarcated in the transcription with double bar lines. The opening segment $(A)$ is in $\mathrm{G}$ minor. The next segment (B), in A minor, begins with an arpeggiated bass pattern, over which Hill places a haunting repeated note melody structured around D5. (This harkens back to the A strain, where D5 is the anchoring and climactic melody note.) In the final segment ( $\left.A^{\prime}\right)$, the basic melodic material from the first segment returns, but Hill remains in A minor before cadencing on the dominant of $\mathrm{B} b$ to set up the next section.

The main thematic cell linking this strain together starts with an ascending two sixteenth-note appoggiatura figure, then skips up a third, peaking on an eighth note, and finally dips down a whole step to a second eighth note. Example 4 is a transcription of this motive in its many manifestations throughout the $\mathrm{D}$ strain.

This motive is harmonized in thirds and sometimes in full tertial sonorities between the upper voices. Against the bass pitches, however, these voices create jarring, dissonant ninths and sevenths. Hill transposes this motive through the various tonal areas of the strain, altering both the contour and rhythm as depicted in Example 4.

In the first appearance of strains $\mathrm{E}$ and $\mathrm{F}$, Hill resumes playing more idiomatically, employing conventional chord progressions and stride bass patterns. The return to the A strain is anticipated very effectively in the F strain, which functions as a large-scale turnaround with a repeated right-hand eighth-note figure that shuttles back and forth between octaves. In the repeat of the form, Hill deconstructs the $\mathrm{E}$ and $\mathrm{F}$ sections, replacing the stride bass with a pseudo-walking bass line, and adding beboppish solo lines loosely based on the original material.

Several styles interact in "Verona Rag," demonstrating Hill's facility in drawing from and synthesizing the jazz tradition. In this study I have tried to cast light on the question of whether these styles complement one another and function symbiotically. Multiple levels of connectivity lend coherence to the piece: the ragtime form, the surface cliché ragtime gestures, all the identifiable Hill-isms, and most of all, the spiritual that the piece is based on. "Verona Rag" is an exemplary illustration of Hill's ability to extend and transform a bygone style and place his indelible mark upon it. However tonal the piece becomes, the constant twists and flexibility of gesture remind the listener that this is Andrew Hill. 

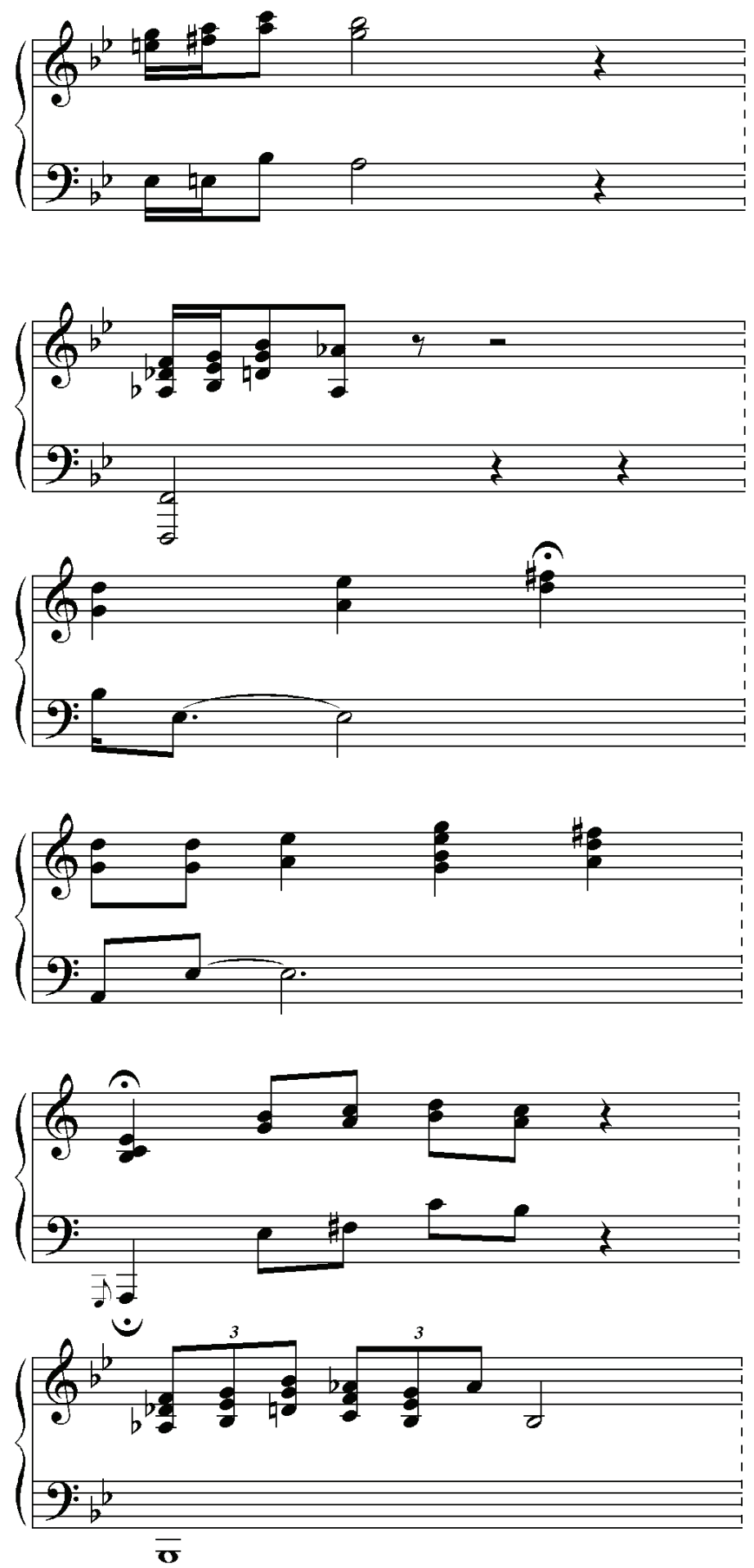

Example 4. Thematic cell and its variations in the D strain. 
Appropriately, the tag of "Verona Rag"—a simple four-bar phrase—encapsulates the opening motivic gesture of "I've Decided To Make Jesus My Choice." After repeatedly developing strands from the spiritual's melody, Hill appropriately ends by quoting almost directly from the source. In the second and third measures of the tag, he overlays this traditional figure with vertical sonorities of his own unique conception: a clever wrap-up and reminder of the styles juxtaposed in this modern rag.

\section{APPENDIX}

The following transcription of "Verona Rag," from the record of the same name, was derived from Hill's first time through the six-strain form. (Hill's interpretation varies slightly each time a strain is repeated.) I have attempted to normalize rhythms and pitches when it seems clear enough what template Hill is working from.

\section{ABOUT THE CONTRIBUTOR}

JEFFREY LOVELL is a graduate teaching fellow at the University of Oregon, where he is completing his $\mathrm{PhD}$ in music theory with a secondary emphasis in jazz studies. He holds a Master's degree in jazz history and research from Rutgers University, and a Bachelor of Music degree in composition from Brigham Young University. 


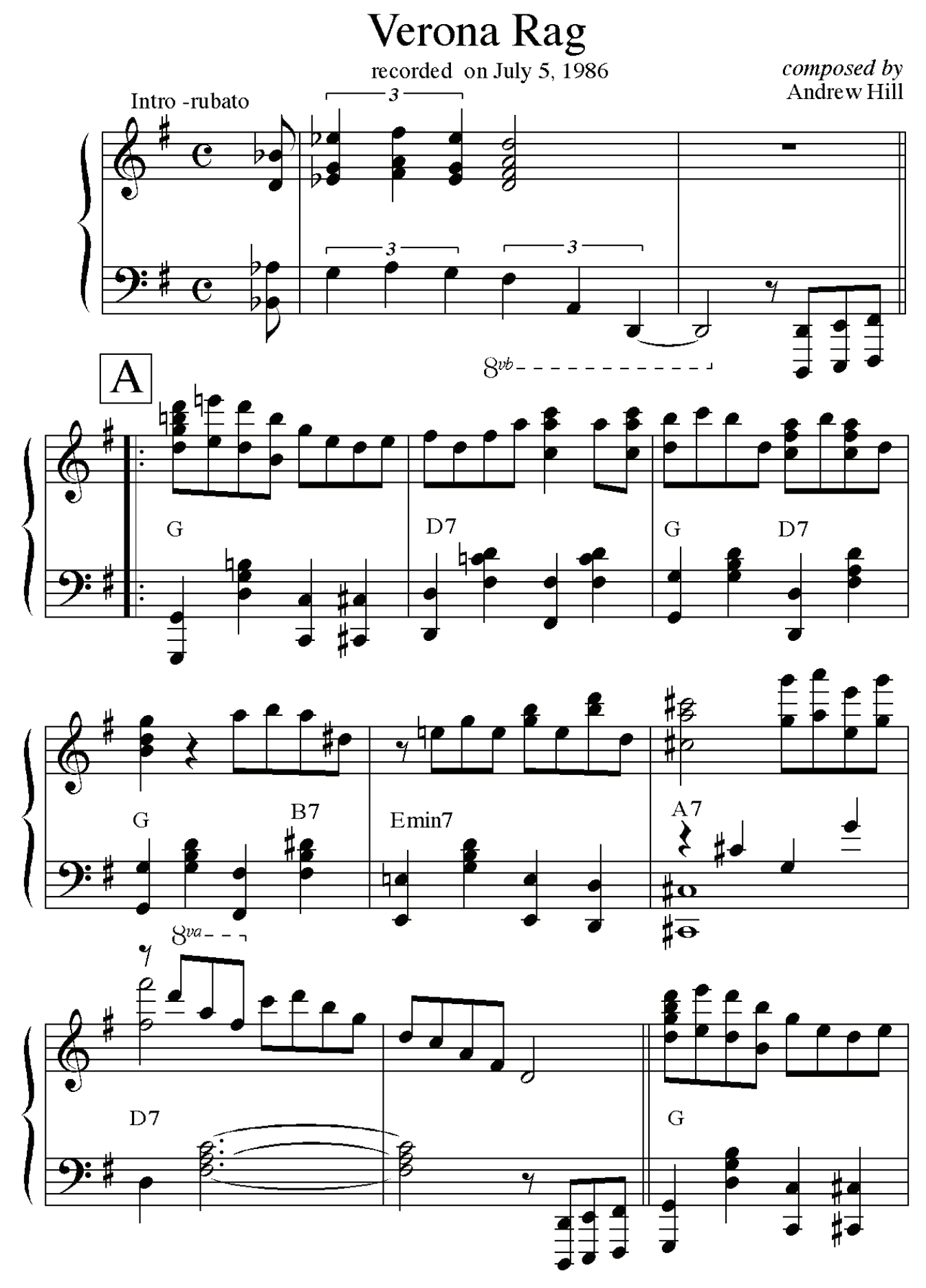

Copyright (C) 1986 by Jazz Fund Music

Hendon Music, Inc., a Boosey \& Hawkes company, Sole Agent Reprinted by permission 

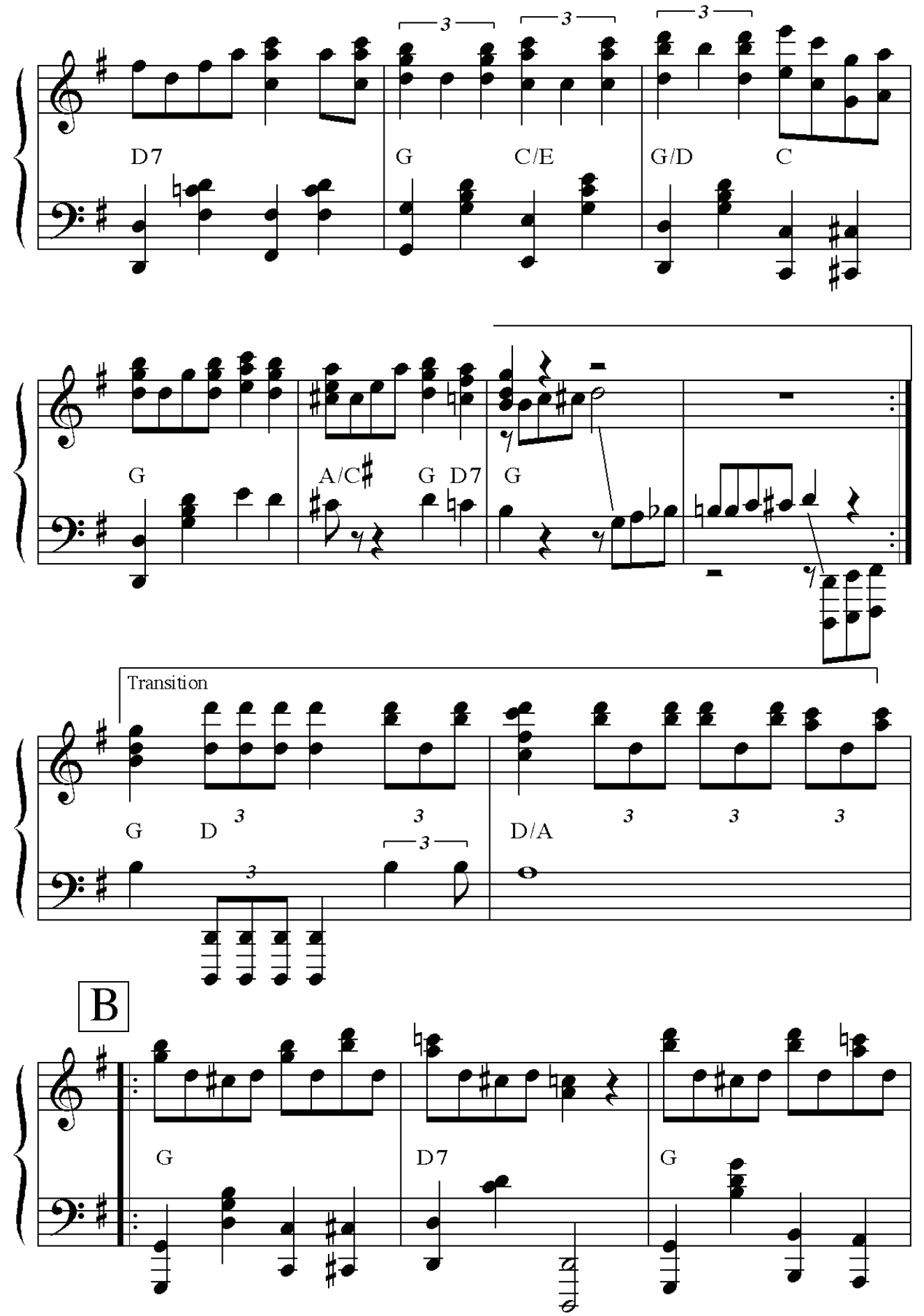

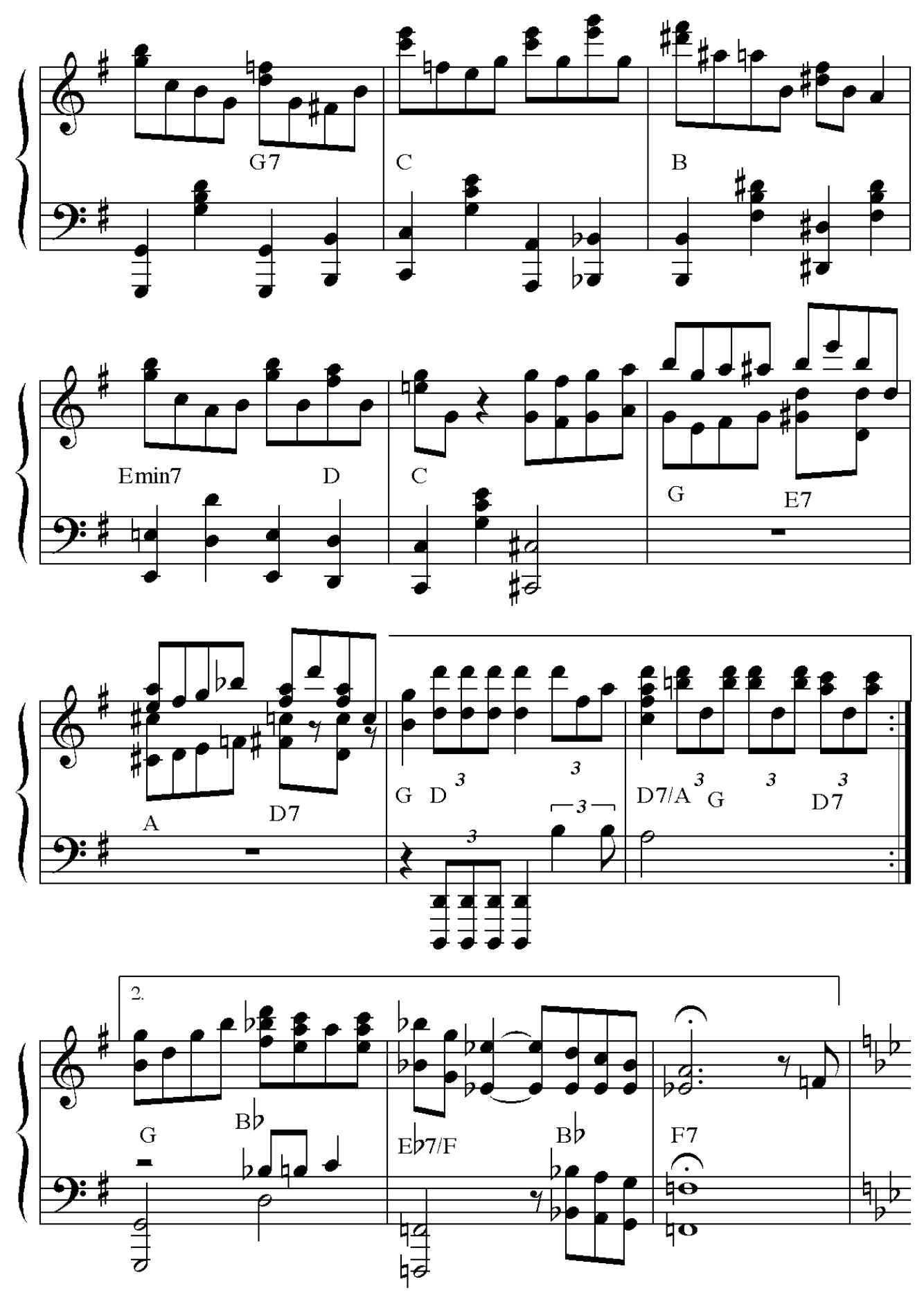

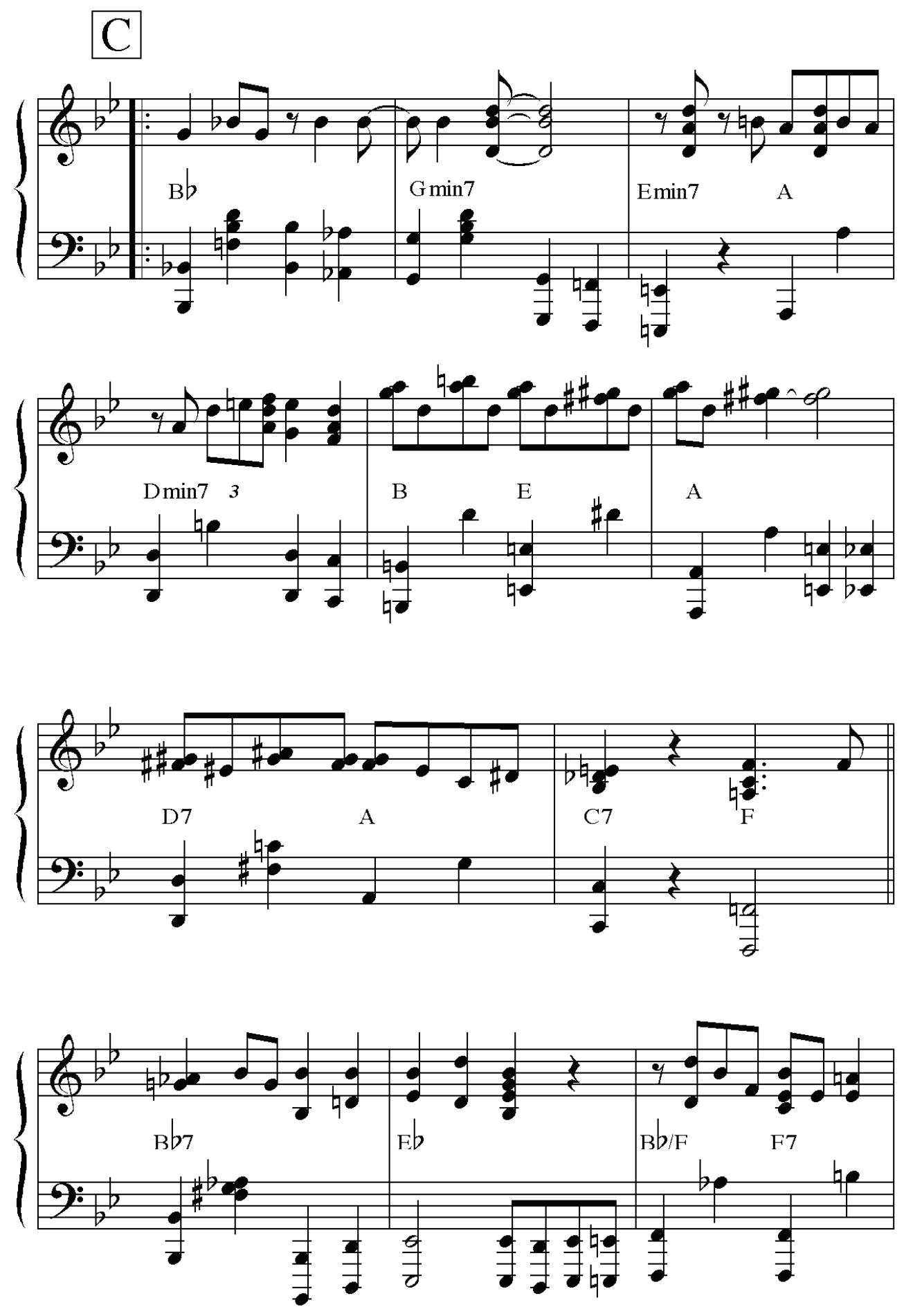

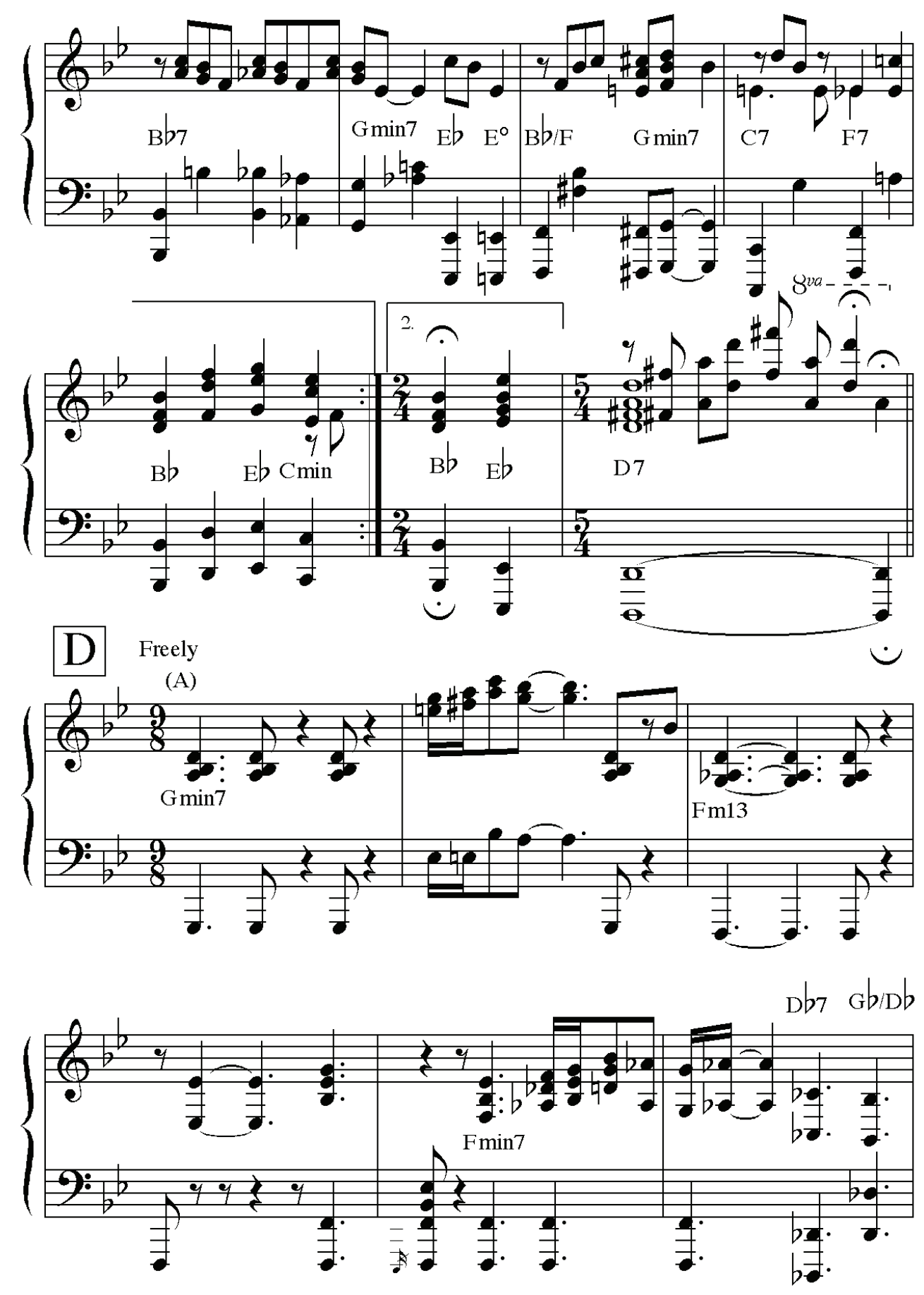


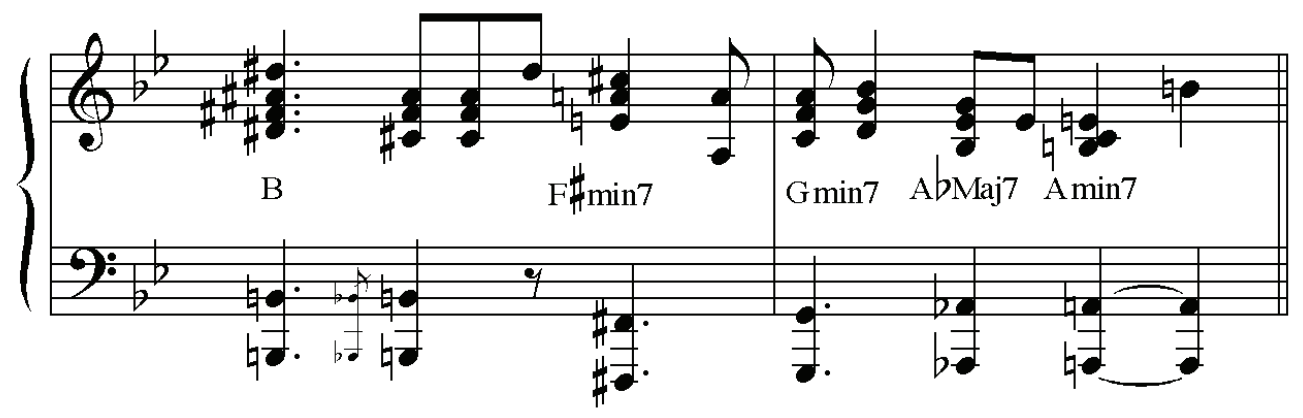

(B)
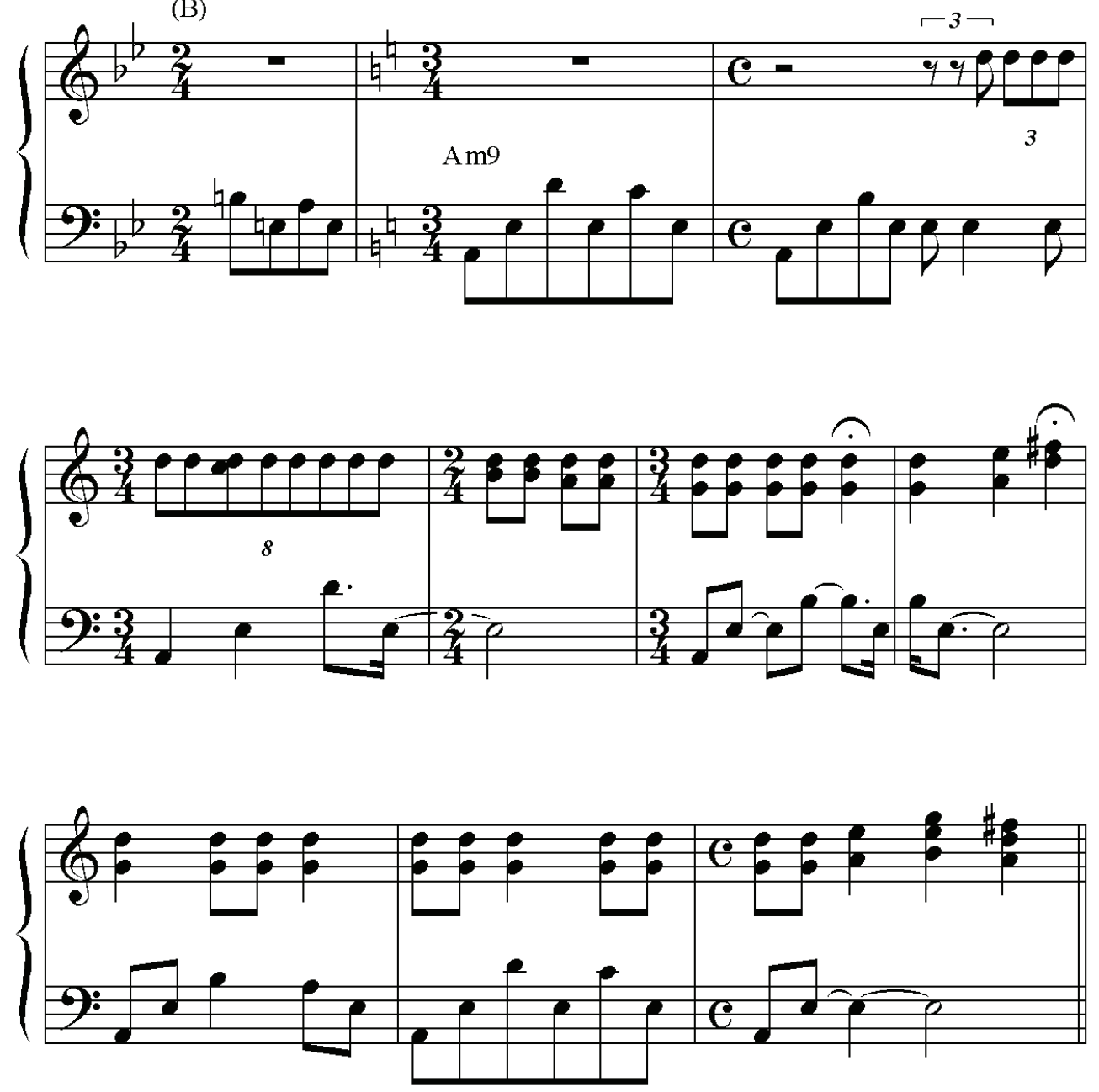

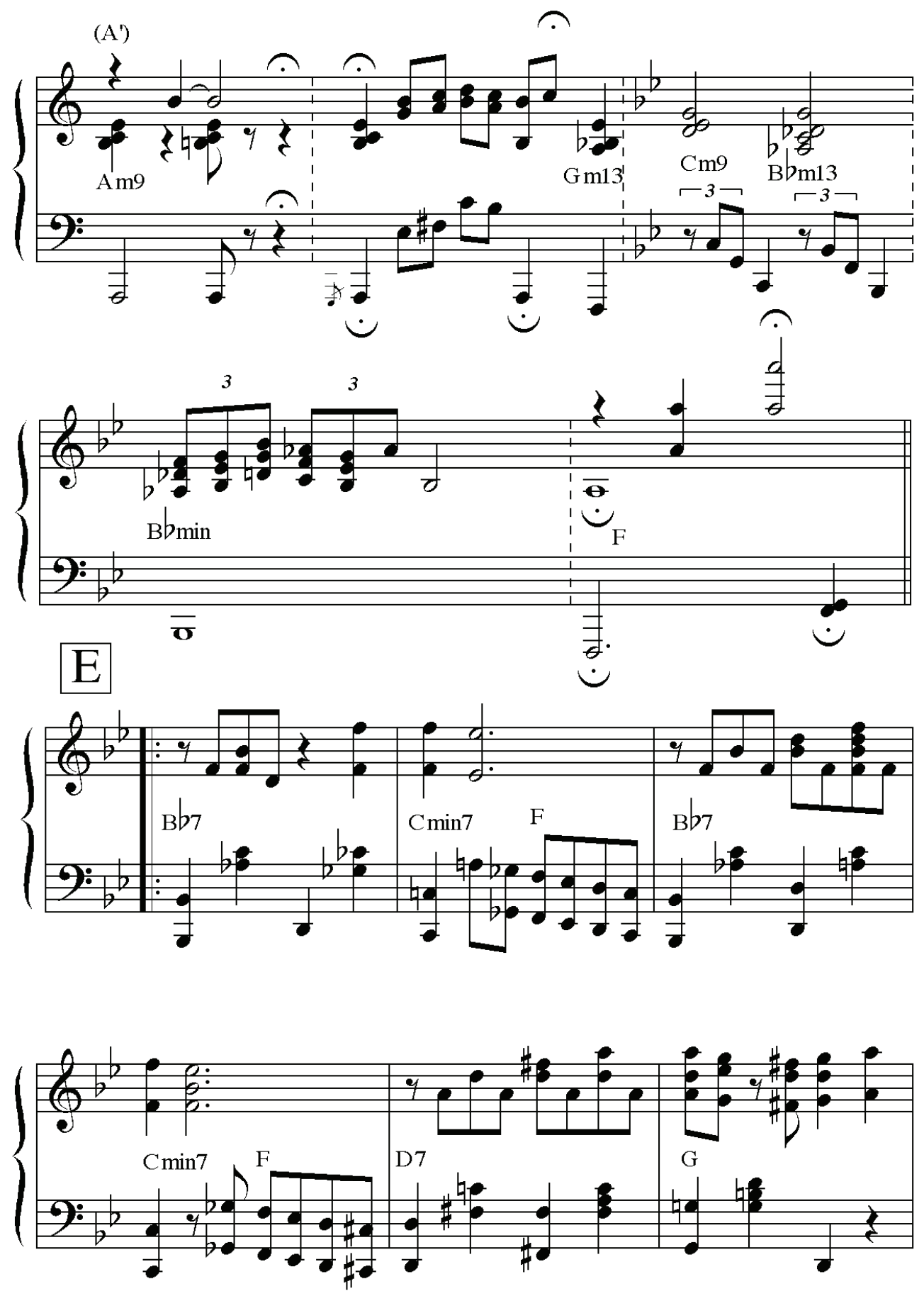

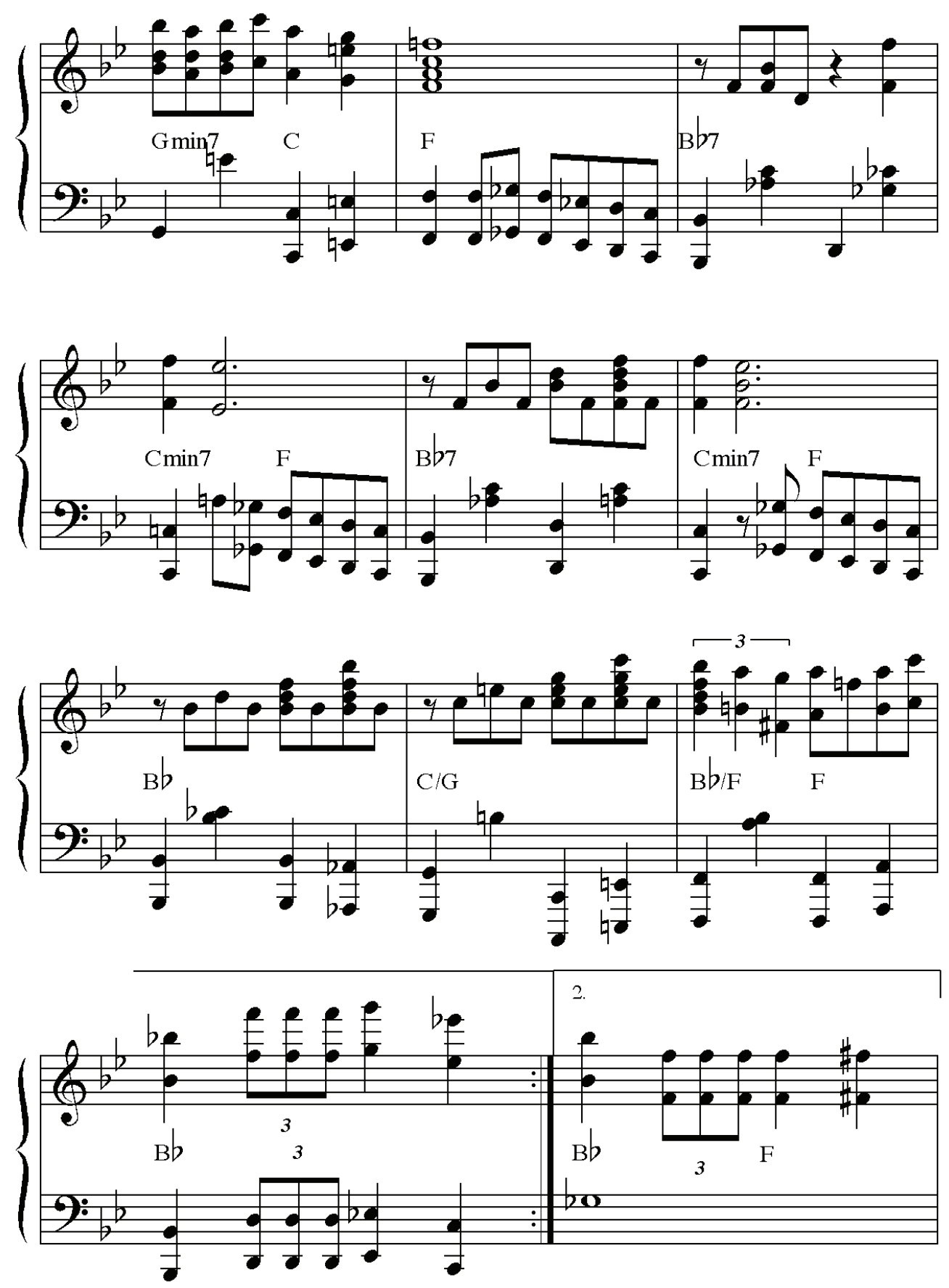

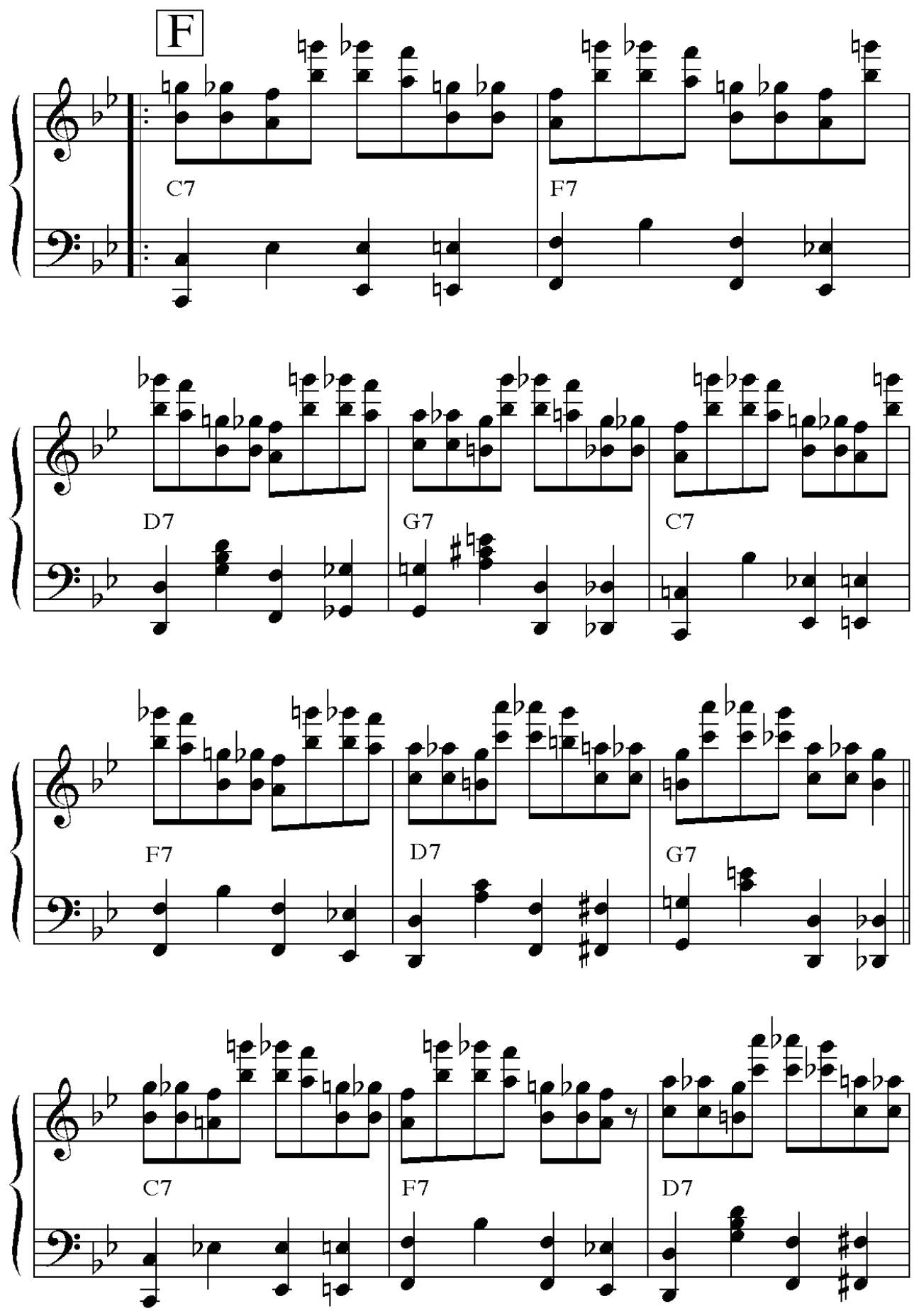

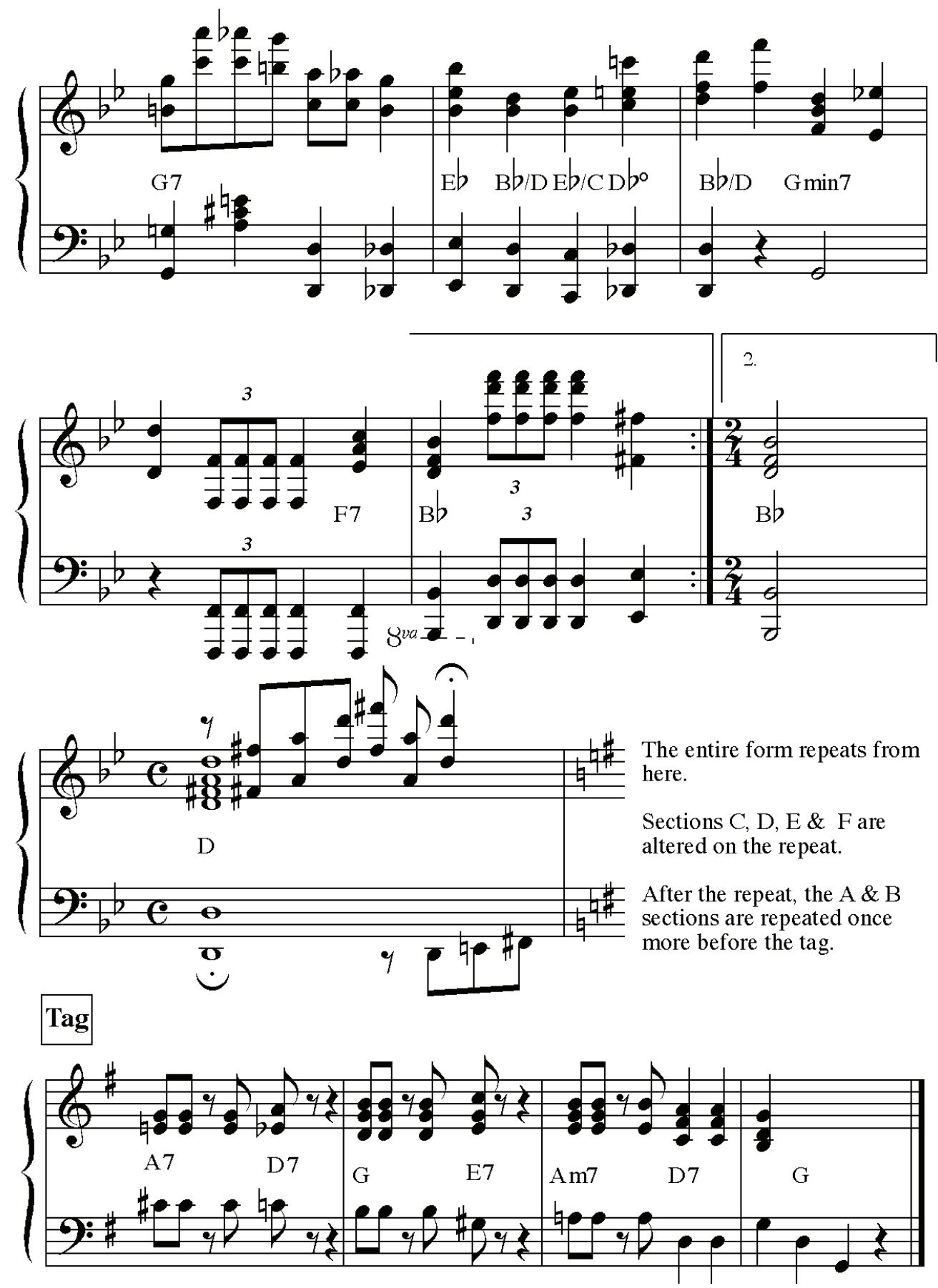

The Journal ofJazz Studies (JJS) is published by the Institute of Jazz Studies at the Newark campus of Rutgers, The State University of New Jersey. The editors of JJS are Edward Berger, Henry Martin, and Dan Morgenstern; the managing editor is Evan Spring. JJS is hosted online by the Rutgers University Libraries at http://jjs.libraries.rutgers.edu. 